\title{
Complicated Triplet Gestation Reduced to Twins with Partial Hydatidiform Mole and a Coexisting Live Fetus: A Case Report Managed in a Tertiary Care Center
}

\author{
Ketki S Kulkarni ${ }^{1}$, Minal P Dhanvij ${ }^{2}$, Anchal Goel ${ }^{3}$
}

\begin{abstract}
Pregnancies with hydatidiform mole and a live fetus are extremely rare, arising in about 1 in 20,000-100,000 pregnancies. Multifetal gestations are increasing due to increase in infertility treatment, and so the complications related to it are on the verge of rising. Also, the partial mole with live fetus is a rare entity, and only few cases are reported in the literature. The objective of the study is reporting a rare case and reviewing the available literature in an attempt to make clinical guidelines. We are reporting a case of 36-year-old, elderly primigravida with in vitro fertilization conception at 29.1 weeks of gestation with severe preeclampsia. She was triplet gestation in early ultrasonography scan reports, and fetal reduction was done at 11 weeks and reduced to twins. A lower segment cesarean section was done, and a healthy male fetus of $1,100 \mathrm{~g}$ was delivered. Placenta of the live triplet and the fetus papyraceous $(200 \mathrm{~g})$ was delivered with a thin cord attached to hydatidiform molar placenta and vesicles. The dilemma is whether to continue such pregnancy or to terminate it, as it is a critical issue to solve. The watchful monitoring of such cases can provide optimum outcome and prevention of metastasis.

Keywords: Coexisting live fetus, Complicated pregnancy, Fetus papyraceous, Partial mole, Triplets.

International Journal of Infertility and Fetal Medicine (2019): 10.5005/jp-journals-10016-1192
\end{abstract}

\section{BACKGROUND}

Pregnancies with hydatidiform mole and a live fetus are extremely rare, arising in about 1 in 20,000-100,000 pregnancies.'

The different possibilities giving rise to this situation are complete mole (diploid, all paternal in origin) coexisting with a normal diploid fetus, a partial mole (triploid, maternal and/ or paternal in origin) coexisting with a normal diploid fetus, and a partial mole with an abnormal triploid foetus. ${ }^{1}$

Clinical dilemma to decide regarding continuation of pregnancy or termination can be addressed by prenatal karyotyping of the coexisting fetus and presence or absence of maternal complications. The management of such pregnancies can be either immediate termination of pregnancy to avoid the potential maternal complications or expectant management. ${ }^{2}$

\section{Case Description}

We present an unusual case of triplet pregnancy with a reduced fetus, a partial hydatidiform mole, and a coexisting live fetus.

A 36-year-old elderly primigravida, married since 3 years, with in vitro fertilization (IVF) conception, 29.1 weeks of gestation, with severe preeclampsia, came in to the casualty with complaints of bleeding per vagina since 7 days soaking one to two pads per day. She was triplet gestation in early ultrasonography reports. At 11 weeks of gestation, fetal reduction was done and triplets reduced to twins. However, at 18 weeks of gestation, an anomaly scan was done which showed fetal demise of one of the fetus along with a reduced fetus and an anatomically normal fetus. At 29 weeks of gestation, she was referred to our institute as a case of complicated triplet gestation-one reduced triplet, one fetal death, and one live coexisting fetus with severe preeclampsia with antepartum hemorrhage.
${ }^{1-3}$ Department of Obstetrics and Gynaecology, Nowrosjee Wadia Maternity Hospital, Mumbai, Maharashtra, India

Corresponding Author: Minal P Dhanvij, Department of Obstetrics and Gynaecology, Nowrosjee Wadia Maternity Hospital, Mumbai, Maharashtra, India, Phone: +91 8421640066, e-mail: minal9star@ gmail.com

How to cite this article: Kulkarni KS, Dhanvij MP, Goel A. Complicated Triplet Gestation Reduced to Twins with Partial Hydatidiform Mole and a Coexisting Live Fetus: A Case Report Managed in a Tertiary Care Center. Int J Infertil Fetal Med 2019;10(3):58-62.

Source of support: Nil

Conflict of interest: None

Her ultrasound was done in labor ward which showed a dead fetus with molar changes in placenta suggestive of partial mole with coexisting live fetus (Fig. 1). Placenta of the live fetus was posterior, not low lying, and no evidence of retro-placental collection or clot. However, the hydatidiform mole showed lower margin $2.5 \mathrm{~cm}$ away from the internal os, and evidence revealed hemorrhage from the lower end. Her serum $\beta$-human chorionic gonadotropin ( $\beta$-hCG) levels were $766,251 \mathrm{mlU} / \mathrm{mL}$. Serum TSH levels were $2.30 \mu \mathrm{IU} / \mathrm{mL}$. She was started on capsule nifedipine 10 mg 6 hourly and tablet labetalol 200 mg 12 hourly. She was given injectable betamethasone, 2 doses 24 hours apart for fetal lung maturity. Her localizing fetal cardiac tracing was done, which was reassuring. However, the patient's blood pressure was worsening, and her bleeding per vagina also did not decrease.

A lower segment cesarean section was done, and a male fetus weighing $1100 \mathrm{~g}$ was delivered, and baby cried immediately after birth. APGAR at 1 minute was 6/10. Placenta of the live triplet was

() The Author(s). 2019 Open Access This article is distributed under the terms of the Creative Commons Attribution 4.0 International License (https://creativecommons. org/licenses/by-nc/4.0/), which permits unrestricted use, distribution, and non-commercial reproduction in any medium, provided you give appropriate credit to the original author(s) and the source, provide a link to the Creative Commons license, and indicate if changes were made. The Creative Commons Public Domain Dedication waiver (http://creativecommons.org/publicdomain/zero/1.0/) applies to the data made available in this article, unless otherwise stated. 


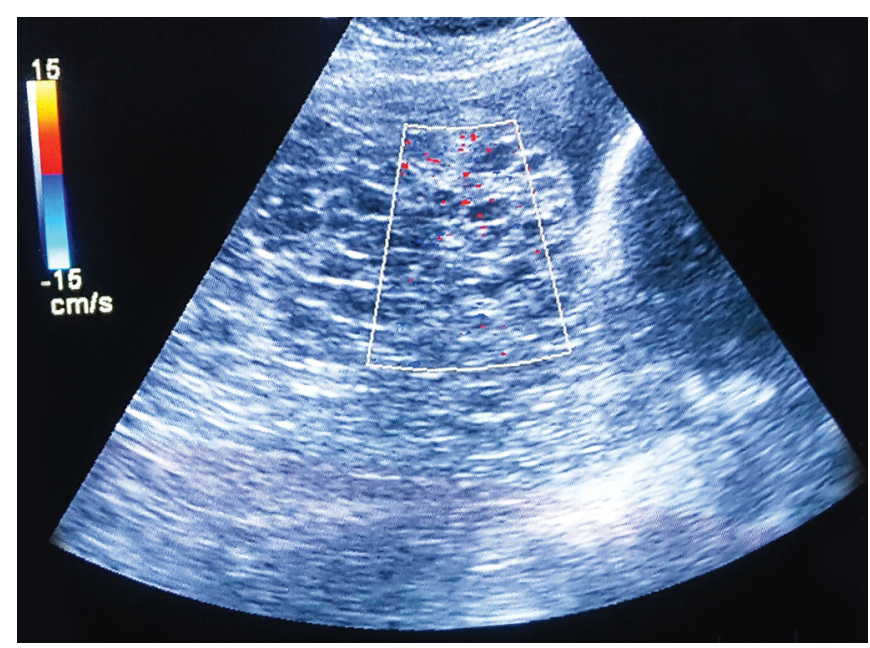

Fig. 1: Ultrasonography picture showing snowstorm appearance of vesicles along the side of fetal head

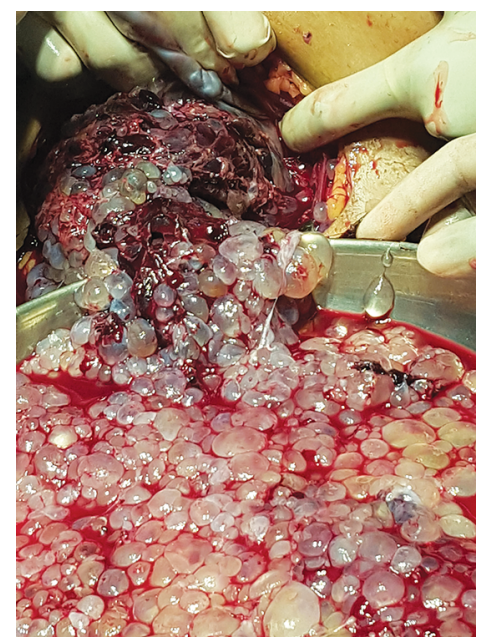

Fig. 3: Hydatidiform molar placenta attached to fetus papyraceous

delivered. Along with it fetus papyraceous $(200 \mathrm{~g})$ was delivered with a thin cord attached to it followed by hydatidiform molar placenta and vesicles (Fig. 2). Around 1.5 liters of vesicles admixed with blood were removed (Fig. 3). Care was taken during cesarean section to avoid spillage of the vesicles in peritoneal cavity by isolation the uterus by packing mops around it before delivery of the placenta. One pint packed red cell and four pints fresh frozen plasma was transfused. Intraoperative ovaries were examined and found to be enlarged and hemorrhagic. Intraperitoneal drain was kept.

Postoperatively, the patient was monitored; however, there was no postpartum hemorrhage, and blood pressure was managed with antihypertensives that were tapered over a period of 8 days, as the blood pressure returned to normal. Chest X-ray done for her was normal. Her $\beta$-hCG levels were monitored, and they showed a decreasing trend (Fig. 4). She was followed till her $\beta$-hCG levels were normal. Histopathological report noted edematous cistern and trophoblastic villous proliferation (Figs 5 and 6).

The neonate was shifted immediately to neonatal intensive unit (NICU) and required surfactant and was on ventilator support for initial few weeks in view of prematurity and low birth weight. The patient was not registered at our center, hence neither antenatal

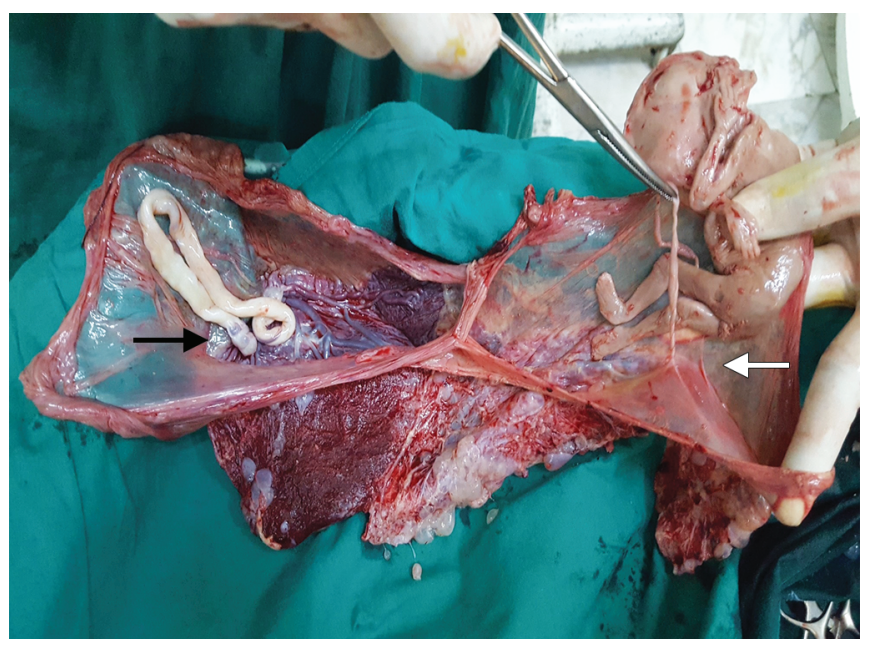

Fig. 2: Placenta of the fetus (black arrow showing placenta and cord of the live fetus and white arrow showing fetus papyraceous with vesicular mole

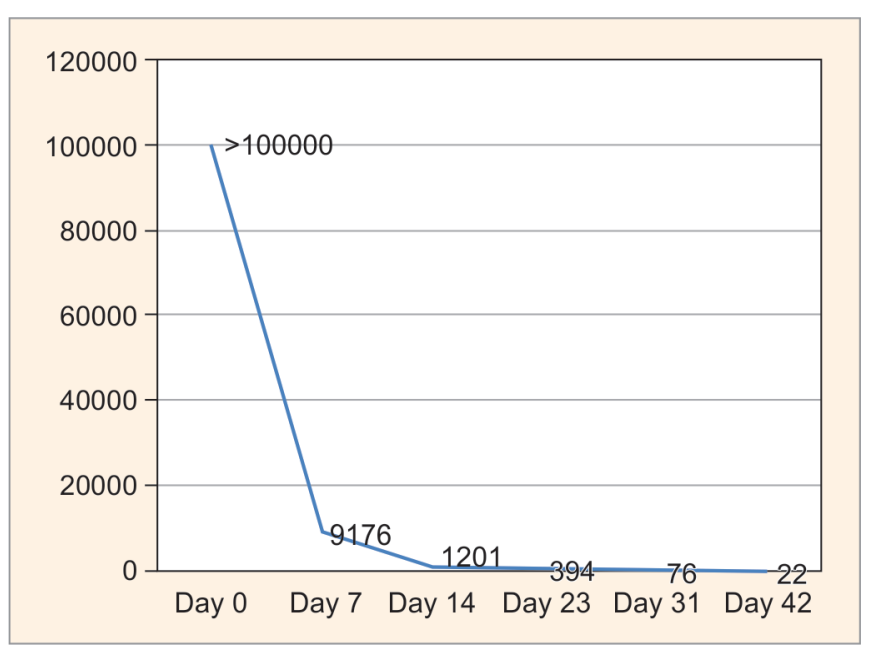

Fig. 4: Line graph showing decreasing trend of S. $\beta$-hCG serially in post LSCS period

karyotyping nor pre-implantation genetic testing was done for her; however, neonate karyotyping was normal. Antepartum karyotyping for intrauterine fetus was not done. After 64 days in the NICU, the neonate was discharged and was in care of mother.

\section{Discussion}

Multi-fetal gestation involving partial mole and coexisting live fetus is a rare entity. Partial molar pregnancy with a live fetus is a very rare condition, occurring in $0.005-0.01 \%$ of all pregnancies. ${ }^{3}$ With the advent of assisted reproduction for infertility treatment, incidence of multiple gestation has increased and so the complications associated with them. Moreover, as most of the women have conceived with assisted reproduction, continuing these pregnancies is desired by them and they are even willing to accept the side effects of the coexisting molar pregnancy. It is hence important to carefully weigh the risks and advantages and draw a line between immediate intervention and expectant management, when health of the pregnant women is not jeopardized as well as the coexisting fetus can be salvaged. 
Table 1 summarizes that 7 (53.84\%) of 13 of the above mentioned cases reported had either aborted or had termination of pregnancy and of them, $5(71.42 \%)$ of 7 were cases of persistent gestational trophoblastic neoplasia (GTN), while $3(42.85 \%)$ of 7 cases also had metastasis. Four (30.76\%) of 13 cases had delivery in late second trimester or early third trimester by cesarean section of which $1 / 4$ (25\%) had persistent GTN, i.e., the case of Sundari et al. had a preterm cesarean section and still had persistent GTN. However, no cases $0 / 4(0 \%)$ had metastasis. Medical termination for second trimester abortion is not recommended as shown by Wang et al. in which persistent GTN as well as metastasis had developed. ${ }^{13}$ Also $4(28.57 \%)$ of 14 cases were conceived by after infertility. In the cases delivered after 28 weeks by cesarean section, all resulted in healthy live born, and the maternal complications could be managed. In our study too, maternal complications like APH and severe preeclampsia had developed; however, cesarean section

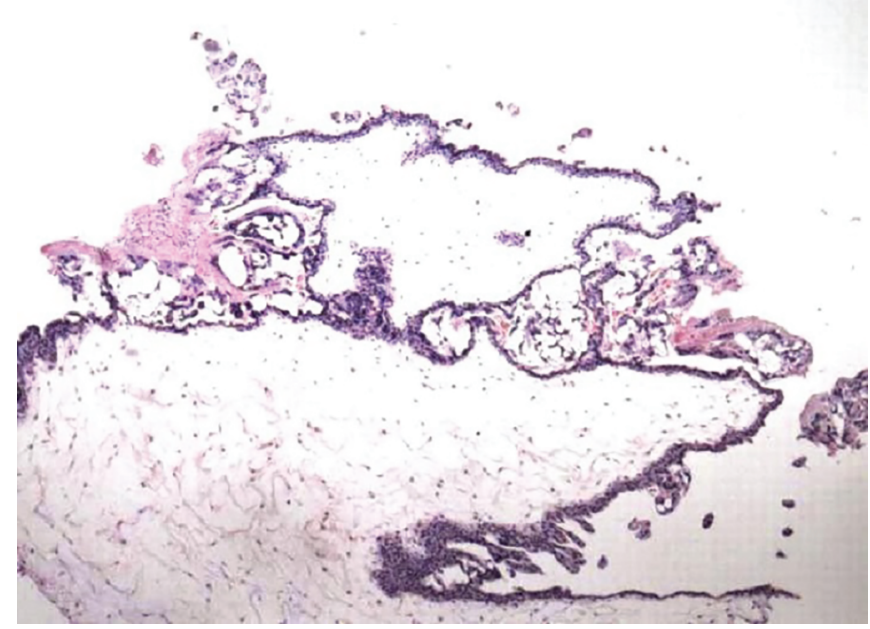

Fig. 5: Hydropic villi with cistern formation and minimal trophoblastic proliferation

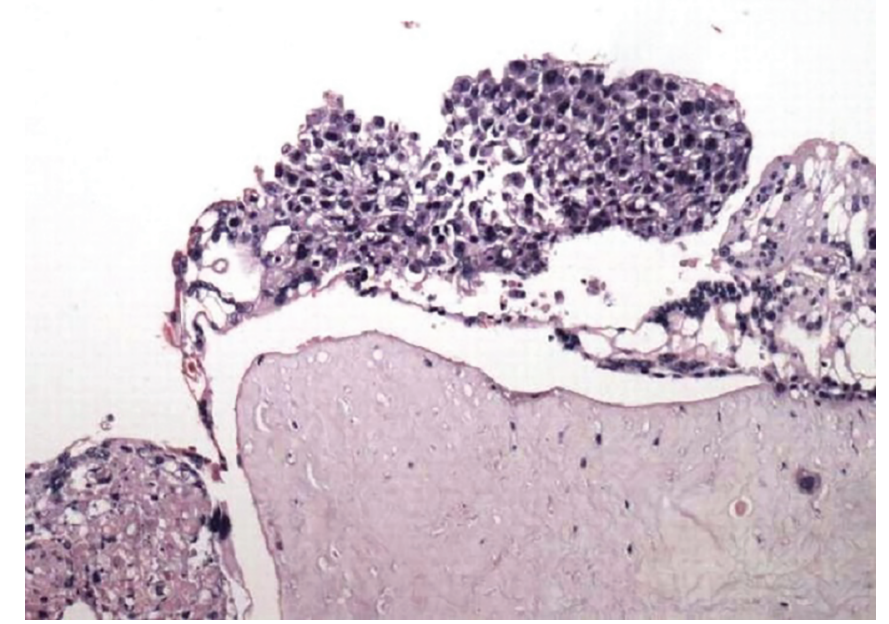

Fig. 6: Heterogeneity in villous size with two discrete populations of villi (large, hydropic villi and small, fibrotic villi) and enlarged villi are irregularly shaped with scalloped borders and secondary trophoblastic pseudo-inclusions

Table 1: Previously reported cases of partial mole with coexisting live fetus in literature

\begin{tabular}{|c|c|c|c|c|c|c|c|c|}
\hline S.no. & Study & Pregnancy status & POG & Complication & PTD & Metastasis & Live born & Mode of delivery \\
\hline 1 & $\begin{array}{l}\text { Marinoff et } \\
\text { al. }^{4}\end{array}$ & $\begin{array}{l}\text { Quadruple with fetal demise } \\
\text { of partial molar fetus, second } \\
\text { trimester abortion of } 2 \text { nd fetus } \\
\text { and coexisting live twins (3rd } \\
\text { and 4th) }\end{array}$ & 32.6 & $\begin{array}{l}\text { Hyperemesis } \\
\text { preeclampsia }\end{array}$ & No & No & Yes, twins & $\begin{array}{l}\text { Preterm vaginal } \\
\text { delayed interval } \\
\text { delivery }\end{array}$ \\
\hline 2 & $\begin{array}{l}\text { Copeland and } \\
\text { Stanek }^{5}\end{array}$ & $\begin{array}{l}\text { Triplet with one embryonic } \\
\text { demise, PM and one coexisting } \\
\text { live fetus }\end{array}$ & 28 & $\begin{array}{l}\text { Worsening } \\
\text { maternal } \\
\text { reflux ne- } \\
\text { phropathy }\end{array}$ & No & No & Yes & Cesarean section \\
\hline 3 & Sundari et al. ${ }^{6}$ & $\begin{array}{l}\text { Triplet partial mole with coexist- } \\
\text { ing live discordant twins. }\end{array}$ & 32.6 & Preeclampsia & Yes & No & $\begin{array}{l}\text { Yes live } \\
\text { born twins }\end{array}$ & Cesarean section \\
\hline 4 & KÜTÜK ${ }^{7}$ & $\begin{array}{l}\text { Triplet with PM selectively termi- } \\
\text { nated (OI+IUI) }\end{array}$ & 20 & $\begin{array}{l}\text { Preeclampsia } \\
\text { hyperthyroid- } \\
\text { ism }\end{array}$ & Yes & No & No & $\begin{array}{l}\text { Spontaneous abor- } \\
\text { tion }\end{array}$ \\
\hline 5 & Kim et al. ${ }^{8}$ & $\begin{array}{l}\text { Triplet with PM. Assisted repro- } \\
\text { duction (IVF conception) }\end{array}$ & 14 & No & Yes & $\begin{array}{l}\text { Yes. Pul- } \\
\text { monary } \\
\text { metastases }\end{array}$ & No & $\begin{array}{l}\text { Termination of preg- } \\
\text { nancy (Top) }\end{array}$ \\
\hline 6 & Zhou et al. ${ }^{9}$ & Twin with PM (IVF conception) & 16 & Invasive mole & Yes* $^{*}$ & $\begin{array}{l}\text { Yes* } \\
\text { Pulmonary } \\
\text { metastases }\end{array}$ & No & Top \\
\hline 7 & Ingec et al. ${ }^{10}$ & Twin with PM & 10 & $\begin{array}{l}\text { Hyperemesis, } \\
\text { hyperthyroid- } \\
\text { ism }\end{array}$ & Yes* & No & No & $\begin{array}{l}\text { Top, suction and } \\
\text { evacuation }\end{array}$ \\
\hline 8 & Tay et al. ${ }^{11}$ & Twin with PM & 11 & & No & No & No & Top, \\
\hline 9 & $\begin{array}{l}\text { Sanchez- } \\
\text { ferrer et al. }{ }^{12}\end{array}$ & Twin with PM & 21 & & No & No & No & $\begin{array}{l}\text { Spontaneous abor- } \\
\text { tion }\end{array}$ \\
\hline
\end{tabular}




\begin{tabular}{|c|c|c|c|c|c|c|c|c|}
\hline S.no. & Study & Pregnancy status & POG & Complication & PTD & Metastasis & Live born & Mode of delivery \\
\hline 10 & Wang et al. ${ }^{13}$ & Twin with PM & 17 & Invasive mole & Yes* & Yes* & No & $\begin{array}{l}\text { Top by induction } \\
\text { by administering } \\
\text { intra-amniotic } \\
\text { Rivanol. (medical } \\
\text { method) And } \\
\text { suction curette for } \\
\text { retained products. }\end{array}$ \\
\hline 11 & Chu et al. ${ }^{1}$ & Twin with PM & 24 & $\begin{array}{l}\text { Threatened } \\
\text { abortion, pre- } \\
\text { term labor }\end{array}$ & No & No & Yes & Cesarean section \\
\hline 12 & $\begin{array}{l}\text { Navarro } \\
\text { Amezcua et } \\
\text { al. }^{14}\end{array}$ & Twin with PM & 29 & $\begin{array}{l}\text { Severe } \\
\text { preeclampsia } \\
\text { severe PPH, } \\
\text { obstetric hys- } \\
\text { terectomy }\end{array}$ & No & No & Yes & $\begin{array}{l}\text { Complicated vaginal } \\
\text { delivery }\end{array}$ \\
\hline 13 & $\begin{array}{l}\text { Our study } \\
(2018)\end{array}$ & $\begin{array}{l}\text { Triplet with reduced fetus with } \\
\text { partial mole with IUFD with one } \\
\text { live fetus (IVF conception) }\end{array}$ & 29.1 & $\begin{array}{l}\text { Severe } \\
\text { preeclampsia } \\
\text { antepartum } \\
\text { hemorrhage }\end{array}$ & No & No & Yes & Cesarean section \\
\hline
\end{tabular}

PTD, persistent trophoblastic disease; PM, partial mole; PPH, postpartum hemorrhage; IUFD, intrauterine fetal demise; IVF, in vitro fertilization

was done at 29.1 weeks, and not only the coexisting live born could be saved but also complete evacuation of the vesicular mole at time of cesarean section was done, and this was easier as evacuation of vesicles was done under vision, and complete evacuation was confirmed, probably the reason for persistent GTN not developing. Also, worsening maternal preeclampsia could also be controlled after delivery. However, in cases of vaginal delivery $>28$ weeks, in one case, there was severe $\mathrm{PPH}$ requiring obstetric hysterectomy.

\section{ConcLusion}

We conclude that for multifetal gestation with partial mole and a coexisting live fetus, second trimester termination of pregnancy may not be a safe option if maternal complications have not developed. Complications like persistent GTN or metastasis are not preventable by termination of pregnancy. Early third trimester delivery by cesarean section may be the better option, as the coexisting liveborn fetus can be saved, risk of persistent GTN and metastasis is low as seen by past case studies, and maternal complications if have started developing can be managed. Waiting to achieve term fetus may increase severity of the maternal complications and may put maternal health and life in jeopardy. However, this is the conclusion of the 13 various case reports. Further large studies are required for laying down guidelines and recommendations.

\section{Clinical Significance}

Women with hydatidiform mole coexistent with a twin live fetus (HMTF) may be allowed to continue pregnancy, provided the fetal karyotype is normal and maternal complications can be controlled. ${ }^{15}$ The overall incidence of preeclampsia in women with HMTF was $30.6 \%$ which is higher compared to women with only complete mole (12.5\%). ${ }^{15}$ The risk of persistent trophoblastic disease after a diploid mole with coexisting fetus pregnancy is similar to that after a singleton molar pregnancy, and expectant management instead of therapeutic abortion can be pursued. ${ }^{16}$ As many of these cases occur after the infertility treatment, the desire to continue pregnancy often outweighs that of termination. Managing these cases are challenging but with vigilant monitoring, optimum outcome is possible.

\section{References}

1. Chu W, Chapman J, Persons DL, et al. Twin pregnancy with partial hydatidiform mole and coexistent fetus. Arch Pathol Lab Med 2004;128:1305-1306.

2. Vaisbuch E, Ben-Arie A, Dgani R, et al. Twin pregnancy consisting of a complete hydatidiform mole and co-existent fetus: Report of two cases and review of literature. Gynecol Oncol 2005;98(1):19-23. DOI: 10.1016/j.ygyno.2005.02.002.

3. Suzuki M, Matsunobu A, Vakita K, et al. Hydatidiform mole with surviving co-existent fetus. Obstet Gynecol 1980;56(3):384-388.

4. Marinoff DN, Spitzberg EH, Chueh JT, et al. Delayed-interval delivery in a quadruplet pregnancy after intrauterine death of a partial molar pregnancy and preterm delivery. a case report. J Reproduct Med 1998;43(12):1051-1054.

5. Copeland JW, Stanek. J. Dizygotic twin pregnancy with a normal fetus and a nodular embryo associated with a partial hydatidiform mole. Pediatr Dev Pathol 2012;13(6):476-480. DOI: 10.2350/09-11-0735-CR.1.

6. Sundari MS, Agarwal P, Mohan J. Triplet pregnancy with partial hydatidiform mole. J Indian Med Assoc 2011;109(2):116-117.

7. KÜTÜK MS, Dolanbay M, Akalın H, et al. Triplet pregnancy with partial hydatidiform mole coexisting with two fetuses after ovulation induction and intrauterine insemination. Gynecol Obstet Reproduct Med 2016;21(3):1300-4751.

8. Kim $\mathrm{CH}, \mathrm{Kim} \mathrm{YH}, \mathrm{Kim}$ JW, et al. Triplet pregnancy with partial hydatidiform mole coexisting with two fetuses: a case report. J Obstet Gynaecol Res 2008;34(4pt2):641-644. DOI: 10.1111/j.14470756.2008.00899.x.

9. Zhou X, Chen Y, Li Y, et al. Partial hydatidiform mole progression into invasive mole with lung metastasis following in vitro fertilization. Oncol Lett 2012;3(3):659-661. DOI: 10.3892/ol.2011.542.

10. Ingec $M$, Borekci B, Altas $S$, et al. Twin pregnancy with partial hydatidiform mole and coexistent normal fetus. J Obstet Gynaecol 2009;26(4):379-380. DOI: 10.1080/01443610600618747.

11. Tay ET. Partial hydatidiform mole and coexisting viable twin pregnancy. Pediatr Emerg Care 2013;29(12):1298-1300. 
12. Sánchez-Ferrer ML, Ferri B, Almansa MT, et al. Partial mole with a diploid fetus: case study and literature review. Fetal Diagn Ther 2009;25(3):354-358. DOI: 10.1159/000235885.

13. Wang Y, Qian H, Wang J. Medical termination of a partial hydatidiform mole and coexisting fetus during the second trimester: a case report. Oncol Lett 2015;10(6):3625-3628. DOI: 10.3892/ol. 2015.3743.

14. Navarro Amezcua ME, Castellanos Reyes J, Cardona González $\mathrm{O}$, et al. Twin pregnancy with partial hydatidiform mole and alive fetus: case report. Obstetricia de Mexico 2008;76(5): 275-279.

15. Matsui H, Sekiya S, Hando T, et al. Hydatidiform mole coexistent with a twin live fetus: a national collaborative study in Japan. Hum Reprod 2000;15(3):608-611. DOI: 10.1093/humrep/15.3.608.

16. Niemann I, Sunde L, Petersen LK. Evaluation of the risk of persistent trophoblastic disease after twin pregnancy with diploid hydatidiform mole and coexisting normal fetus. Am J Obstet Gynecol 2007;197(1):45. e1-5. DOI: 10.1016/j.ajog.2007.02.038. 